STUDIA POLONIJNE

T. 36. Lublin 2015

DOI: http://dx.doi.org/10.18290/sp.2015.4

JACEK JAN GOŁĘBIOWSKI

\title{
ELITY POLSKIE W LONDYNIE PO II WOJNIE ŚWIATOWEJ
}

\section{GENEZA „POLSKIEGO LONDYNU”}

Masowy wymiar emigracji polskiej w Wielkiej Brytanii jest związany z działalnością Polskich Sił Zbrojnych na Zachodzie i rządu Rzeczypospolitej Polskiej na emigracji podczas II wojny światowej. Wojenny i wojskowy charakter tej emigracji uzależniony był ponadto od kwestii politycznej przyszłości Polski i nowego ładu w Europie po zakończeniu wojny. Nowy ,jałtański porządek” w powojennej Europie i podział świata na dwa bieguny: USA i sojusznicy oraz ZSRR i państwa satelickie zadecydowały o pozostaniu około 500 tysięcy Polaków na Zachodzie.

Ta nowa wielka fala polskiej emigracji politycznej, słusznie nazywana obecnie „II wielką emigracją”, miała ogromny wpływ na formy organizacyjne życia społeczno-kulturalnego emigrantów polskich zarówno w Wielkiej Brytanii, jak i w innych państwach Zachodu.

W chwili zakończenia II wojny światowej na Wyspach Brytyjskich przebywało 95000 Polaków, z czego 54234 było żołnierzami, 21744 cywilami (dane Home Office), a około 20000 służyło w lotnictwie, marynarce wojennej i służbach pomocniczych. Do tej liczby w latach 1945-1947 dołączyło około 200 tysięcy żołnierzy PSZ (żołnierze II Korpusu gen. W. Andersa, I Dywizji Pancernej gen. S. Maczka, I Dywizji Spadochronowej gen. S. Sosabowskiego etc.), z których

Dr hab. JACEK JAN GOŁĘBIOwSKI, prof. KUL - dyrektor Ośrodka Badań nad Polonią i Duszpasterstwem Polonijnym KUL; e-mail: jacekgolebiowski@kul.pl 
95000 zaryzykowało powrót do Polski. Poza repatriacją do Ojczyzny część polskich emigrantów wybrała dalszą podróż do USA, Kanady, Australii czy też państw Ameryki Południowej (głównie Argentyny).

Według brytyjskich danych w październiku 1949 r. na terenie Zjednoczonego Królestwa przebywało około 160000 Polaków. Do Polskiego Korpusu Przysposobienia i Rozmieszczenia wstąpiło 114000 żołnierzy i oficerów, z czego 20000 reemigrowało bądź udało się w dalszą podróż w poszukiwaniu zatrudnienia (casus Argentyny) ${ }^{1}$.

Generalnie należy stwierdzić, iż cechą wyróżniającą polską emigrację po II wojnie światowej w Wielkiej Brytanii był niespotykanie wysoki odsetek inteligencji i ziemiaństwa (elit II Rzeczypospolitej, które uniknęly zbrodniczej ręki nazistów i komunistów).

Według danych Polskiego Korpusu Przysposobienia i Rozmieszczenia około 10000 polskich emigrantów miało wyższe wykształcenie zawodowe. Było wśród nich 65 profesorów i wykładowców wyższych uczelni, 319 nauczycieli szkół średnich i 690 nauczycieli szkół powszechnych, 131 dziennikarzy, 54 pisarzy i literatów, 617 prawników, 400 aktorów, malarzy i rzeźbiarzy, 850 urzędników sądownictwa, 64 architektów, 71 duchownych, ponad 1000 inżynierów, 790 lekarzy i dentystów, 302 farmaceutów, ponad 2500 urzędników państwowych i 1800 urzędników zatrudnionych w prywatnych przedsiębiorstwach i bankach ${ }^{2}$. Była to elita narodu polskiego, której poczucie polskiej tożsamości, głęboka świadomość historyczna oraz silna identyfikacja z religią katolicką wpłynęły na rozwój i formy działalności licznych organizacji polonijnych na terenie Wielkiej Brytanii, polskiej oświaty i polskiej prasy.

Inteligencki charakter polskiej emigracji wpłynął na osiedlanie się jej w wielkich miastach, przy czym fenomenem było osiedlenie się 80\% Polaków w Londynie. Wielka Brytania w odróżnieniu od Stanów Zjednoczonych i Kanady nie wypracowała rządowego programu asymilacji czy integracji, co sprzyjało tworzeniu dużej zbiorowości polskiej.

\footnotetext{
${ }^{1}$ W samej Argentynie liczbę polskich inżynierów i techników, którzy napłynęli po wojnie do argentyńskiego przemysłu, górnictwa i budownictwa, szacuje się na około 2 tysiące osób. Fakt ten miał ogromne znaczenie dla rozwoju gospodarki argentyńskiej. Ponadto wielu wybitnych polskich specjalistów zostało zatrudnionych w Argentyńskich Zakładach Zbrojeniowych (np. A. Żebrowski, specjalista od broni i amunicji ppanc., W. Hanke, specjalista od lotnictwa, A. Kowalczyk, specjalista od balistyki rakietowej itd.). Polscy profesorowie, wykładali na argentyńskich uniwersytetach i wyższych uczelniach wojskowych.

2 T. RADZIK, Spoteczność polska w Wielkiej Brytanii w latach 1945-1990, w: Polonia w Europie, red. B. Szydłowska-Ceglowa, Poznań 1992, s. 440-441.
} 
Głównym powodem ogromnego zaangażowania się polskich elit w działalność polonijnych instytucji, organizacji, szkolnictwa i prasy była deklasacja zawodowa wszystkich emigrantów związana $\mathrm{z}$ podjęciem zarobkowej pracy fizycznej. Dotyczyło to wszystkich od najwyższych rangą wojskowych (gen. Sosabowski, gen. Maczek, gen. Klemens Rudnicki, gen. Fabrycy, gen. Bór-Komorowski, gen. Kordian Zamorski), polityków i pozostałej części inteligencji.

\section{ELITY POLITYCZNE „POLSKIEGO LONDYNU”}

Wycofanie 5 lipca 1945 r. przez Wielką Brytanię, USA, Francję i inne państwa uznania dla polskiego rządu emigracyjnego w Londynie zmieniło radykalnie jego pozycję międzynarodową (uznawały go nadal: Hiszpania, Irlandia, Kuba, Liban i Stolica Apostolska), nie spowodowało jednak jego likwidacji. Na emigracji nadal funkcjonował system partyjny i grono znanych polityków, istniała baza materialna oraz dziesiątki tysięcy emigrantów, którzy nigdy nie pogodzili się z politycznym zniewoleniem Polski i sowietyzacją. Na następne 45 lat Londyn stał się polityczną stolicą polskiej emigracji. W ramach emigracyjnej państwowości widziano oprócz instytucji politycznych organizacje i przedsięwzięcia niepolityczne takie jak naukę, oświatę, prasę oraz zrzeszenia społeczne a nawet Bank Emigracyjny. Wszystkie razem miały tworzyć strukturę przypominającą normalne państwo. Materialną podstawę jego działania, a także niezależność od obcych zapewnić miał Skarb Narodowy. Powołany do życia w 1949 r., trudnił się gromadzeniem funduszy, w przeważającej mierze dobrowolnych składek pochodzących od Polaków rozsianych po świecie. Tak urządzona państwowość była formą kontynuacji II RP oraz alternatywą dla komunistycznej PRL ${ }^{3}$.

\footnotetext{
${ }^{3}$ W 1959 r. Skarb Narodowy obchodził swoje dziesięciolecie, jak podaje Edward Sołtys w swojej pracy Parlament na Obczyźnie (Toronto 2006), w latach 1949-1958 zebrano kwotę 575281 dolarów amerykańskich. Najwięcej pieniędzy zebrano w Europie (301 288 \$), w tym w samej Wielkiej Brytanii (181 528). Owocna zbiórka pochodziła z USA (176 349), Kanady (40 023), Australii (8038) oraz z Afryki (6914).

W roku jubileuszowym Skarbem Narodowym kierowała Główna Komisja, w skład której wchodzili: gen. Władysław Anders, Jan Baliński-Jundziłł, Józef Baraniecki, gen. Tadeusz Bór-Komorowski, Mieczysław Chmielewski, Adam Ciołkosz, Antoni Dargas, Zygmunt Dygat, Władysław Folkierski, Władysław Juchniewicz, gen. Marian Kukiel, Stanisław Lis, Stanisław Misiakowski, Zygmunt Nowakowski, gen. Roman Odzieżyński, Stanisław Pelc, Zygmunt Podhorski, Bogdan Podoski, Edward Raczyński, Tadeusz Romer, Kazimierz Sabat, Alfred Sas-Korczyński, Stefan Soboniewski, Stanisław Sopicki, gen. Kazimierz Sosnowski, Zbigniew Stypułkowski, Zygmunt Sza-
} 
Rząd w Londynie dysponował przedstawicielami we wszystkich skupiskach polskich oraz własną służbą dyplomatyczną. Funkcje nieoficjalnych ambasadorów pełnili zawodowi dyplomaci II RP, m.in. Juliusz Łukasiewicz, Józef Lipski, Kajetan Morawski czy też Kazimierz Papée.

Parlamentaryzm polski w Wielkiej Brytanii łączył tradycyjne stronnictwa II RP, takie jak Stronnictwo Narodowe, Polska Partia Socjalistyczna, Polskie Stronnictwo Ludowe, Stronnictwo Pracy, z ugrupowaniami odpryskowymi ruchu ludowego, socjalistycznego i chadeckiego, takimi jak Związek Socjalistów Polskich na Obczyźnie, Stronnictwo Ludowe „Wolność” oraz nowymi partiami ukształtowanymi na emigracji, np.: Liga Niepodległości Polski, Niezależna Grupa Społeczna, Niezależny Ruch Społeczny, Konwent Walki o Niepodległość, Polski Ruch Wolnościowy Niepodległość i Demokracja etc. Zadania polityczne polskiego wychodźstwa w Wielkiej Brytanii zostały zdefiniowane w Odezwie Rządu Rzeczypospolitej z 26 czerwca 1945 r. Czytamy w niej m.in.:

[...] Rząd polski nie może zgodzić się na oderwanie połowy terytorium narodu polskiego, łącznie z miastami tak drogimi dla całego narodu polskiego, jak Lwów i Wilno.

Rząd polski nie może zgodzić się na narzucenie Polsce ustroju socjalnego, obcego jej podstawowym pojęciom pokoju, zasadom prawa i tradycjom moralnym.

Rząd polski nie może się zgodzić na uznanie żadnych praw samozwańczego komitetu, złożonego przeważnie z członków partii komunistycznej i podległego obcemu państwu.

Rząd polski nie może się zgodzić na niszczenie prawnego porządku, na którym jest oparta egzystencja państwa polskiego.

Rząd polski nie może się zgodzić na zerwanie tysiącletnich więzów pomiędzy Polską a światem zachodniej kultury i cywilizacji [...]

Wartości moralne naszej cywilizacji, obecnie podeptanej, zostaną odrodzone i w końcu zwyciężą. Z całej swej mocy musimy dążyć do przyspieszenia tego odrodzenia. W tym okresie każdy Polak ma przed sobą doniosłe zadanie. Pierwszym obowiązkiem jest zachowanie godności naszego narodu przez wykazanie dyscypliny i opanowania, przez solidarność, przez nieskazitelność życia publicznego i prywatnego. Na każdym stanowisku i na każdym polu Polacy muszą dać przykład nieugiętości, pracy i twórczego wysiłku. Przyszły los Polaków nie będzie jednakowy. Gdy większa część będzie znosić okropną rzeczywistość systemu policyjnego, inni pozostaną w wolnym świecie, aby być rzecznikami tych co muszą milczeć.

Droga naszej przyszłości jest trudna, lecz u kresu naszej wędrówki zobaczymy Polskę, za którą wszyscy walczymy z całego serca. Polskę wolną i niepodległą, Polskę wolności i sprawiedliwości, Polskę w której zwycięży miłość Boga i ludzi .

dowski, Tymon Terlecki, Mieczysław Thugutt, Leon Woroniewicz, ks. Adam Wróbel, Wacław Zagórski i Karol Poznański.

${ }^{4}$ Odezwa Rządu Rzeczypospolitej z dnia 26 czerwca 1945. Dodatek do „Dziennika Polskiego i Dziennika Żołnierza” z 27 czerwca 1945 r. 
Wychodźstwo polskie w Wielkiej Brytanii nie tylko podtrzymało, ale imponująco rozwinęło budowaną podczas II wojny światowej wokół rządu emigracyjnego sieć instytucji życia społecznego, kulturalnego i politycznego. Fakt, iż większość ocalałej z pożogi wojennej przedwojennej elity politycznej i kulturalnej osiedliła się w Zjednoczonym Królestwie, sprzyjał aktywności intelektualnej polskiego środowiska emigracyjnego.

Historię ,polskiego Londynu" współtworzyli wybitni przedstawiciele wszystkich warstw polskiej elity uformowanej podczas niepodległego dwudziestolecia II Rzeczypospolitej Polskiej.

$\mathrm{Na}$ emigracji w Wielkiej Brytanii znaleźli się najważniejsi dowódcy, oficerowie i żołnierze Polskich Sił Zbrojnych na Zachodzie. Byli wśród nich generałowie: Władysław Anders, Stanisław Maczek, Józef Haller, Stanisław Kopański, Stanisław Sosabowski, Klemens Rudnicki, Tadeusz Bór-Komorowski, Kazimierz Fabrycy, Stefan Dąb-Biernacki, Józef Zamorski, Marian Kukiel, Kazimierz Sosnkowski i inni. Ich los podzielili wybitni przedstawiciele świata polityki i dyplomacji, tacy jak: Władysław Raczkiewicz, Edward Raczyński, August Zaleski, Tomasz Arciszewski, Adam Ciołkosz, Tadeusz Bielecki, Jędrzej Giertych, Wojciech Wasiutyński, Władysław Folkierski, Stanisław Stroński, Wiktor Trościanko, Antoni Dargas, Stanisław Grabski, Tymon Terlecki, Rowmund Piłsudski, Stanisław Cat-Mackiewicz, Antoni Pająk, Aleksander Zawisza i wielu innych.

Do tego znakomitego grona należy doliczyć wybitnych twórców kultury, do których należeli: Jan Lechoń, Kazimierz Wierzyński, Józef Czapski, Maria Kuncewiczowa, Zofia Kossak-Szczucka, Józef Mackiewicz, Juliusz Mieroszewski, Sergiusz Piasecki, Melchior Wańkowicz, Marian Hemar, Tadeusz Żenczykowski, Leopold Pobóg-Kielanowski, Zygmunt Nowakowski, Feliks Konarski, Włada Majewska, Regina Kowalewska, Mieczysław Grydzewski, Aleksander Bregman, Stefania Kossowska i inni.

\section{NAJWAŻNIEJSZE TYTUŁY PRASOWE}

Zdecydowanie inteligencki charakter polskiego wychodźstwa w Londynie znalazł swoje odzwierciedlenie w niewiarygodnie wielkiej liczbie tytułów prasowych, periodyków i biuletynów. Ich łączna liczba w latach 1945-1989 wynosi 
838 tytułów ${ }^{5}$. Wiele $\mathrm{z}$ nich na stałe wpisało się w dzieje polskiej społeczności na Wyspach Brytyjskich. Prasa polska w Zjednoczonym Królestwie odegrała poważną rolę $w$ pielęgnowaniu kultury i tradycji niepodległościowych II Rzeczypospolitej Polskiej. Była niezwykle ważnym elementem konsolidacji środowiska polskiego i jednocześnie czynnikiem utrwalającym polską tożsamość narodową na emigracji.

Do najważniejszych tytułów prasowych należą:

1. „Dziennik Polski i Dziennik Żołnierza” - zaczął wychodzić w Londynie od lipca 1940 r. jako „Dziennik Polski”, a w 1944 r. gazeta została połączona $\mathrm{z}$ „Dziennikiem Żołnierza”. Docierał do większych skupisk polonijnych nie tylko w UK. Nakład około 30000 egz. sprawił, iż było to najbardziej opiniotwórcze pismo polskiej emigracji politycznej, antykomunistyczne, patriotyczne, kultywujące najpiękniejsze tradycje i wartości niepodległej Polski. Atrakcyjne dodatki: weekendowy „Tydzień Polski” i „Środa literacka”.

Redaktorzy: Tadeusz Hurko i Aleksander Bregman (od 1959 r.). Pisali w nim najwybitniejsi przedstawiciele emigracji: Stanisław Stroński, Marian Kukiel, Marian Hemar, Zygmunt Nowakowski, Feliks Łobodowski i wielu innych. Dziennik zaprzestał swojej tradycyjnej drukowanej formy w lipcu $2015 \mathrm{r}$. i rozpoczął kontynuację tytułu wyłącznie w wersji elektronicznej.

2. „Gazeta Niedzielna” - tygodnik ukazujący się przy współudziale Polskiej Misji Katolickiej w Anglii, odwołujący się do przedwojennej tradycji przystępnych pism katolickich. Redaktorzy: Józef Kisielewski, Jan Bielatowicz, Andrzej Onyszkiewicz, Tadeusz Borowicz, Bohdan Wroński, Zdzisław Wałaszewski. Nakład około 8000 egz. „Gazeta Niedzielna” miała mutację w Holandii (,Polak w Holandii”) i we Francji („Głos Katolicki”) oraz dodatki „Gazetę Literacką” i „Polskę Walczącą”. Zawierała informacje o życiu religijnym polskiej diaspory, komentarze polityczne, artykuły na aktualne tematy, kronikę wydarzeń polskiego życia w Londynie, wiadomości polityczne, odcinek powieściowy, recenzje i serwis wiadomości krajowych. Dzięki wysokiemu poziomowi i artykułom filozoficzno-etycznym była chętnie czytana przez inteligencję katolicką na wychodźstwie. Na jej łamach pisali m. in.: Jan Bielatowicz, Wacław Netter, Wojciech Płazak, Józef Jasnowski, Alicja Moskalowa, Paweł Skwarczyński, Aleksandra Podhorodecka, ks. Zygmunt Kwiatkowski i inni.

\footnotetext{
${ }^{5}$ Biblioteka Polska w Londynie, Indeks tytułów prasy polskiej w Wielkiej Brytanii w latach 1945-1989.
} 
3. „Wiadomości” - założone przez Mieczysława Grydzewskiego w 1946 r., były kontynuacją przedwojennych „Wiadomości Literackich”. Na łamach tygodnika pisywali najważniejsi emigracyjni pisarze i publicyści, m.in.: Zygmunt Nowakowski, Adam Pragier, Stanisław i Józef Mackiewiczowie, Józef Wittlin, Ferdynand Goetel, Jan Lechoń, Kazimierz Wierzyński i Marian Kukiel. Po śmierci Grydzewskiego kontynuowane przez Michała Chmielowca i Zofię Kossowską (przestało wychodzić w 1981 r.).

4. „Myśl Polska” - główny organ Stronnictwa Narodowego na emigracji. Pismo wydawane od 20 marca 1941 r. w Londynie, początkowo jako dwutygodnik $\mathrm{z}$ dodatkiem $\mathrm{w}$ języku angielskim poświęconym skarbom kultury polskiej i polskiemu wkładowi w cywilizację Europy Zachodniej, później jako miesięcznik. Pierwszym redaktorem naczelnym był Marian Emil Rojek, następnie Tadeusz Bielecki, Wojciech Wasiutyński i Antoni Dargas. Wysoki poziom intelektualny pisma zapewniali znakomici publicyści (W. Wasiutyński, W. Folkierski, W. Trościanko, J. Giertych, A. Tybulewicz, T. Bielecki, W. Górski). Promowało polskość na emigracji i dokonywało bieżących analiz stosunków polsko-sowieckich i polsko-niemieckich w kontekście zmian zachodzących w Europie. W roku 1992 przeniesione do Warszawy.

5. „Orzeł Biały” - tygodnik polityczno-literacki II Korpusu gen. Andersa o kierunku ,niepodległościowym”. Wydawany od 7 grudnia 1941 r. w Buzułuku (ZSRR), towarzyszył w drodze bojowej żołnierzom. Od 1949 r. wychodził w Londynie. Redagowany przez Ryszarda Piestrzyńskiego i Pawła Zarembę, stał na straży wartości niepodlegających rewizji, często był polemiczny wobec paryskiej „Kultury”. W składzie kolegium redakcyjnego znajdowali się: Ryszard Piestrzyński (redaktor naczelny), Jerzy Drobnik, J. Ostrowski, T. Szypniewski. Od 1964 r. związane z SPK.

6. „Życie” - katolicki tygodnik religijno-kulturalny, wydawany w latach 1947-1959 przez Veritas Foundation Publication Centre w Londynie. Redagowany przez pisarza Józefa Kisielewskiego oraz Jana Bielatowicza. „Życie” miało mutację w Holandii - „Życie. Polak w Holandii”. Tygodnik był rozprowadzany w Anglii, Argentynie, Australii, Belgii, Brazylii, Danii, Francji, Holandii, Kanadzie, Norwegii, USA, Szwajcarii, Szwecji i Włoszech. Prezentował wysoki poziom, uważany był za najlepszy emigracyjny tygodnik o charakterze religijnym, sporo uwagi poświęcał sytuacji Kościoła w Polsce i w świecie. Oprócz tekstów o tematyce religijnej zawierał felietony historyczne, wiadomości, fragmenty prozy, poezję i recenzje. Pisali w nim: M. Rojek, 
W. Wasiutyński i J. Giertych, M. Bohusz-Szyszko, Tymon Terlecki, ks. Stanisław Bełch. „Życie” utrzymywało kontakt z inteligencją katolicką w kraju.

7. ,Jutro Polski” - organ prasowy Polskiego Stronnictwa Ludowego na emigracji, początkowo jako tygodnik później jako kwartalnik, wydawany w Londynie w latach 1942-1992. Redaktorami byli: Stanisław Młodożeniec, Władysław Grabski i Franciszek Wilk. Na łamach pisma dyskutowano nad ustrojem przyszłej wolnej Polski, zwracano szczególną uwagę na kwestie społeczne i konieczność upodmiotowienia wszystkich warstw społecznych. W artykułach historycznych podnoszono zalety ustroju Rzeczypospolitej Obojga Narodów (artykuły prof. Oskara Haleckiego, Stanisława Kutrzeby i prof. Oswalda Balzera).

8. „Rzeczpospolita Polska” - oficjalny organ rządu Rzeczypospolitej Polskiej na uchodźstwie, początkowo wydawany w formie dwutygodnika, a następnie miesięcznika. Pismo ukazywało się w latach 1957-1991. Zawierało kronikę prac i działalności rządu, przegląd najważniejszych wydarzeń politycznych na emigracji i w kraju. Redaktorami byli: Wacław Grubiński, Jerzy Gawęda i Jan Walewski.

9. „Wiadomości Nauczycielskie” - miesięcznik wydawany przez Zrzeszenie Nauczycielstwa Polskiego za Granicą od maja 1943 r. Redaktorem był Mieczysław Grygielewicz. Pismo poruszało najważniejsze zagadnienia dotyczące kształcenia nauczycieli i uczniów polskich na emigracji. Było wielką pomocą dla środowisk prowadzących nauczanie języka i przedmiotów ojczyźnianych w polskich szkołach sobotnich.

10. „Wiadomości PMK - Czyn Katolicki” - pismo Polskiej Misji Katolickiej w Wielkiej Brytanii i Walii oraz Instytutu Polskiej Akcji Katolickiej założone w roku 1938. W wyżej wymienionej wersji zaczęło wychodzić od roku 1963 jako kwartalnik, a od 1980 r. jako miesięcznik. Redaktorzy: Józef Kisielewski, ks. Aleksander Ralston-Gogoliński-Elston, Andrzej Onyszkiewicz. W piśmie publikowano artykuły popularnonaukowe, filozoficzne i literackie. Omawiano problematykę dotyczącą religijności na emigracji, relacji Kościoła katolickiego z anglikańskim, zagadnień dwukulturowości i problematyki rodziny. Pisali w nim m.in.: abp Szczepan Wesoły, Józef Kisielewski, Kazimierz i Maria Mochlińscy, Wacław Netter.

11. „Wychowanie Ojczyste” - kwartalnik pedagogiczny dla nauczycielstwa i rodziców, wydawany przez Zarząd Główny Polskiej Macierzy Szkolnej Zagranicą. Ukazywał się w latach 1955-1985, następnie jako „Wychowanie i Słowo Ojczyste” i „Słowo Ojczyste. Magazyn Pedagogiczny”. Redaktorami 
byli: Jan Wajs, Michał Goławski i Jerzy Samborski. W części oświatowo-metodycznej pismo zawierało liczne materiały lekcyjne, ćwiczenia i pomoce do nauki języka polskiego oraz lekcje pokazowe. Zamieszczano w nim artykuły historyczne z dziejów Polski, walki o niepodległość, zasługi Polaków w II wojnie światowej oraz na emigracji, dzieje literatury polskiej oraz utwory literackie i teatralne dla uczniów.

12. „Teki Historyczne” - należały do osobnej grupy czasopism londyńskich jako periodyki naukowe. Wydawały je wszystkie działające w Londynie towarzystwa naukowe. ,Teki Historyczne” były organem Polskiego Towarzystwa Historycznego w Wielkiej Brytanii. Redagowane były od roku 1947 przy znaczącym udziale generała Mariana Kukiela. Sekcja muzealna Towarzystwa wydawała kwartalnik „Broń i Barwa”.

13. „Kontynenty - Nowy Merkuriusz” - miesięcznik wydawany w Londynie w latach 1959-1966. Redaktorami byli: Adam Czerniawski, Bogdan Czajkowski, Florian Śmieja i Bolesław Taborski. Pismo było krytyczne wobec tradycyjnie konserwatywnego środowiska ,polskiego Londynu”. Podejmowało tematy stosunków polsko-niemieckich, gospodarki i kultury w komunistycznej Polsce, roli Kościoła katolickiego etc. Miesięcznik był adresowany do młodej polskiej inteligencji, która w poszukiwaniu własnej tożsamości kontestowała nienaruszalne imponderabilia pokolenia swoich rodziców związanych z tradycją II Rzeczypospolitej Polskiej.

14. „Lwów i Wilno” - tygodnik redagowany przez Stanisława Cata-Mackiewicza znakomicie dowodzący wagę Kresów Wschodnich i ich zasługi dla rozwoju polskiej kultury.

15. „Polemiki” - kwartalnik historyczny wydawany nakładem wydawnictwa Polonia przez Andrzeja Stypułkowskiego, pomyślany jako antidotum na załamania historiografii PRL, szczególnie dotyczące historii XX wieku. Pisywali w nim: Aleksander Bregman, Paweł Zaremba, Adam Ciołkosz.

Obecność silnie zintegrowanego środowiska polskiego uchodźstwa politycznego w Londynie sprzyjała nie tylko powstawaniu licznych tytułów prasowych, ale także dodatnio wpływała na rozwój wydawnictw, towarzystw naukowych, szkół i organizacji polonijnych.

Łączna liczba wydanych książek i broszur w Wielkiej Brytanii przekracza kilka tysięcy egzemplarzy.

Wiele z nich dotyczyło historii Polski, literatury, kultury, edycji źródeł, pamiętników i tematyki polityczno-społecznej nieobecnej z racji cenzury w krajowym obiegu czytelniczym. 
Do najważniejszych oficyn wydawniczych ,polskiego Londynu” należały: Książnica Polska, Polish Book Depot, Caldra House, Montgomeryshire Printing Co., Orbis. Wszystkie rozpoczęły działalność podczas II wojny światowej. Najdłużej z nich na rynku utrzymał się Orbis kierowany przez Aleksandrę i Jerzego Kulczyckich (wielkich przyjaciół i dobroczyńców Katolickiego Uniwersytetu Lubelskiego Jana Pawła II).

Kolejna ważna oficyna wydawnicza to Gryf Publication Ltd. (1946 r.), znany dzięki hitom wydawniczym takim, jak Władystaw Anders, Bez ostatniego rozdziału czy też Najnowsza historia polityczna Polski Władysława Pobóg-Malinowskiego.

Trzecim po Orbisie i Gryfie szczególnie ważnym wydawnictwem polskim w Londynie jest Katolicki Ośrodek Wydawniczy Veritas (od 1947 r.), który ma na swoim koncie ponad 700 wydanych książek. Poza wymienionymi wydawnictwami na uwagę zasługują: działająca od 1963 r. Polska Fundacja Kulturalna, wydająca głównie beletrystykę i książki z najnowszej historii polski, oraz związane z tzw. emigracją solidarnościową wydawnictwa Polonia, Puls i Aneks. Wydawnictwa te wywarły wielki wpływ na środowiska opozycyjne w kraju, do czego przyczyniła się ich polityka wydawnicza publikująca także autorów krajowych poza cenzurą ${ }^{6}$. Cechą charakterystyczną wydawnictw polskiego Londynu było publikowanie na potrzeby kraju. Dzięki wydawnictwom emigracyjnym udało się skutecznie zahamować proces sowietyzacji młodego pokolenia inteligencji polskiej w kraju, polegający na zakłamywaniu najnowszej historii Polski. Historycy emigracyjni związani z Londynem, jak gen. Kukiel, Tadeusz Żenczykowski, Władysław Pobóg-Malinowski, Jędrzej Giertych, Wojciech Wasiutyński, Jan Ciechanowski, Adam i Lidia Ciołkoszowie, Aleksander Bregman czy uczestnicy wydarzeń, tacy jak gen. Władysław Anders, gen. Stanisław Maczek, Edward Raczyński i wielu innych wpłynęli swoją twórczością na świadomość narodowej tożsamości całego pokolenia młodej inteligencji polskiej lat osiemdziesiątych.

\section{4. ŻYCIE ORGANIZACYJNE POLSKIEGO WYCHODŹSTWA W LONDYNIE}

Kolejnym, bardzo ważnym świadectwem niezwykłej żywotności i wytrwałej pracy na rzecz zachowania narodowej tożsamości polskiej emigracji politycznej w Londynie jest działalność organizacyjna. Obejmuje ona wszystkie pola społecz-

\footnotetext{
${ }^{6}$ T. RADZIK, Spoteczność polska w Wielkiej Brytanii w latach 1945-1990, s. 462-464.
} 
nej aktywności od religii, poprzez naukę i oświatę, kulturę, organizacje zawodowe, kombatanckie, młodzieżowe aż po stowarzyszenia i organizacje hobbystyczne. Podobnie jak w przypadku prasy, liczba polskich organizacji w Wielkiej Brytanii szacowana na kilkaset, $\mathrm{w}$ tym kilkadziesiąt o charakterze ponadlokalnym może budzić uzasadniony podziw. Tak znaczna liczba organizacji i stowarzyszeń wymagała instytucji koordynującej działalność. Funkcję tę od roku 1947 pełni do chwili obecnej Zjednoczenie Polskie w Wielkiej Brytanii. Zjednoczenie skupia obecnie 70 największych organizacji polskich o charakterze ponadlokalnym, reprezentowanych w Radzie Zjednoczenia proporcjonalnie do swej liczebności. Siedzibą Zjednoczenia jest budynek Polskiego Ośrodka Społeczno-Kulturalnego w Londynie w licznie zamieszkałej przez Polaków dzielnicy Hammersmith.

Do najważniejszych organizacji polskich mających siedzibę $\mathrm{w}$ Londynie należały:

1. Organizacje kombatanckie - Stowarzyszenie Polskich Kombatantów (obecnie Fundacja SPK), Związek Lotników Polskich, Stowarzyszenie Marynarki Wojennej, Związek Inwalidów Wojennych etc.

2. Organizacje naukowe i oświatowe - Polskie Towarzystwo Naukowe na Obczyźnie, Polskie Towarzystwo Historyczne, Instytut Polski i Muzeum im. Gen. Sikorskiego, Biblioteka Polska, Instytut Józefa Piłsudskiego, Towarzystwo im. Romana Dmowskiego, Towarzystwo Popierania Nauki Polskiej, Polish Heritage Society, Polski Ośrodek Naukowy, Polska Fundacja Kulturalna, Fundacja „Veritas”, Polska Macierz Szkolna, Instytut Wschodni „Reduta”, Instytut Badania Zagadnień Krajowych etc.

3. Organizacje zawodowe - Związek Nauczycielstwa Polskiego za Granicą, Związek Pisarzy Polskich na Obczyźnie, Stowarzyszenie Prawników Polskich, Związek Dziennikarzy, Stowarzyszenie Techników Polskich, Związek Artystów Scen Polskich, Związek Polskich Artystów Plastyków, Związek Lekarzy Polskich na Obczyźnie, Związek Kupców, Przemysłowców Polskich i Właścicieli Nieruchomości, Stowarzyszenie Rolników Polskich etc.

4. Organizacje religijne - Polska Misja Katolicka na Anglię i Walię, Instytut Polskiej Akcji Katolickiej, Sekretariat Sodalicji Mariańskich na Wychodźstwie etc.

5. Organizacje opiekuńcze i pomocowe - Towarzystwo Pomocy Polakom, Komitet Obywatelski Pomocy Uchodźcom z Polski, Food for Poland etc.

6. Organizacje młodzieżowe - Związek Harcerstwa Polskiego, Katolickie Stowarzyszenie Młodzieży Polskiej, Polska YMCA (Young Men's Christian Association). 
7. Inne - Polski Ośrodek Społeczno-Kulturalny, Polish Aid Foundation Trust, Fundacja Armii Krajowej, Fundacja z Brzezia Lanckorońskich, Stowarzyszenie Rodzin Osadników Kresowych, Stowarzyszenie Lwowian, Kijowian, Stanisławowian, Stryjan etc.

Ukazana powyżej krótka charakterystyka organizacji i stowarzyszeń polskiej emigracji politycznej w Wielkiej Brytanii dowodzi, iż mówienie o fenomenie polskości na Wyspach Brytyjskich nie jest żadną przesadą, tylko stwierdzeniem faktu. Przez 45 lat powojennej historii zwarte środowisko polskiego wychodźstwa nie tylko zachowało, ale w poważnym stopniu rozwinęło struktury organizacyjne wytworzone przez rząd na uchodźstwie, kontynuując rolę centrum polskiej diaspory walczącej o wolną Ojczyznę. Czynnikami sprzyjającymi utrzymaniu narodowej tożsamości i przekazaniu polskości kolejnemu pokoleniu były:

- izolacja od komunistycznej Polski i jej agend w obcym językowo i kulturowo środowisku,

- powszechna świadomość wychodźstwa o kontynuacji legalizmu władz II Rzeczypospolitej Polskiej i konieczności zachowania dla przyszłych wolnych pokoleń Polaków najcenniejszych wartości ideowych i etycznych niepodległej Ojczyzny,

- odtworzenie na emigracji silnych struktur religijnych w postaci Polskiej Misji Katolickiej i polskich parafii ${ }^{7}$,

- wybór kardynała Karola Wojtyły na najwyższy urząd Kościoła Katolickiego i związana z tym faktem eksplozja dumy narodowej Polaków rozsianych po całym świecie,

- powstanie Niezależnego Samorządnego Związku Zawodowego „Solidarność" i przejęcie przez Polskę roli lidera przemian społeczno-politycznych w Europie Środkowo-Wschodniej ${ }^{8}$.

\footnotetext{
${ }^{7}$ Polska Misja Katolicka w Wielkiej Brytanii powstała w 1894 r., jednakże jej gwałtowny rozwój datuje się od czasu II wojny światowej, kiedy to liczne rzesze polskich żołnierzy i emigrantów objęła opieką duszpasterską, charytatywną i patriotyczną. Po wojnie PMK objęła swoją opieką około 120 tysięcy Polaków mieszkających na terenie Anglii i Walii, zorganizowanych w 70 parafiach (dziś ta liczba wynosi 103 i przejawia stałą tendencję wzrostową związaną z rosnącą liczbą Polaków w Zjednoczonym Królestwie).

${ }^{8}$ Polacy w Wielkiej Brytanii bardzo aktywnie włączali się w akcje pomocy walczącym z reżimem komunistycznym rodakom. Kilkanaście polskich organizacji w Londynie wysyłało zebrane pieniądze, artykuły żywnościowe, leki, książki, odzież etc. O skali pomocy świadczą liczby, Medical Aid for Poland i Food for Poland wysłały leki i żywność o wartości powyżej 2 mln 250 tysięcy funtów brytyjskich. Fundusz Pomocy Krajowi wysłał 180 tysięcy funtów na wszechstronną pomoc działaczom opozycyjnym.
} 
Elity polskie w Londynie wypełniły swoją dziejową rolę depozytariusza narodowego dziedzictwa niepodległej Ojczyzny, chroniącego, dla przyszłych wolnych pokoleń, najcenniejsze wartości kształtujące polską tożsamość narodową. Najważniejsze z nich to umiłowanie Boga i Ojczyzny, umiłowanie wolności, kierowanie się w życiu społecznym dobrem wspólnym, honor i duma z polskości.

\section{BIBLIOGRAFIA}

RADZIK T., Społeczność polska w Wielkiej Brytanii w latach 1945-1990, w: Polonia w Europie, red. B. Szydłowska-Ceglowa, Poznań: PAN 1992.

SOŁTYS E., Parlament na Obczyźnie, Toronto: Canadian Polish Research Institute 2006.

\section{POLISH ELITES IN LONDON AFTER THE SECOND WORLD WAR}

Su m mary

The article discusses the process of developing a strong and well-organized Polish diaspora in the United Kingdom. The mass influx of Poles to the British Isles took place during the Second World War and was connected with the activities of the Government of the Republic of Poland in exile and with the Polish Armed Forces in the West. The Sovietization of Poland and the change of its borders caused that about 500,000 Poles remained in the West after the war. The largest concentration of Polish expatriates was the United Kingdom. The political and intellectual nature of this emigration and its location in London and some major British cities have caused it to become a catalyst for the explosion of numerous Polish organizations, associations, educational and cultural institutions, parishes, schools and the press. The article's author offers a detailed analysis of the examples of the intellectual activity of Polish emigrants in Great Britain.

Key words: Polish emigration in Great Britain; Polish heritage of Great Britain.

Translated by Karolina Jurak

\section{ELITY POLSKIE W LONDYNIE PO II WOJNIE ŚWIATOWEJ}

\section{Streszczenie}

Artykuł omawia proces powstawania silnej i dobrze zorganizowanej polskiej diaspory w Wielkiej Brytanii. Masowy napływ Polaków na Wyspy Brytyjskie miał miejsce podczas drugiej wojny światowej i związany był z działalnością Rządu RP na uchodźstwie oraz z Polskimi Siłami Zbrojnymi na Zachodzie. Sowietyzacja Polski i zmiana granic Rzeczy- 
pospolitej spowodowała, iż około 500 tysięcy Polaków pozostało po wojnie na Zachodzie. Największym skupiskiem emigrantów polskich było Zjednoczone Królestwo. Polityczny i inteligencki charakter tej emigracji oraz jej lokalizacja w Londynie i kilku głównych miastach Wielkiej Brytanii spowodowały, że stała się ona katalizatorem eksplozji licznych polskich organizacji, stowarzyszeń, instytucji nauki i kultury, parafii, szkolnictwa oraz prasy. Autor artykułu szczegółowo prezentuje przykłady aktywności intelektualnej polskiego wychodźstwa w Wielkiej Brytanii.

Słowa kluczowe: Polska emigracja w Wielkiej Brytanii; polskie dziedzictwo Wielkiej Brytanii. 